Arkivoc

Free to Authors and Readers
A Platinum Open Access Journal for Organic Chemistry

Paper

DOAJ Seal
Arkivoc 2021, part v, 15-23

\title{
Synthesis of new pyrrolo[3,4-b]indol-3-ones as latent substrates for pyrrolo[3,4-b]indoles
}

Mark G. Saulnier, Steven M. Schreiber, Kerri L. Cavanaugh, Robert B. Perni, H. Howard Joyner, and Gordon W. Gribble*

Department of Chemistry, Dartmouth College, Hanover, NH 03755, USA

Email: ggribble@dartmouth.edu

This paper is in celebration of the retirement of Peter A. Jacobi: friend, colleague, outstanding researcher, and consummate educator

Received 09-14-2020

Accepted 09-29-2020

Published on line $10-04-2020$

\section{Abstract}

We report the synthesis of new examples of the 1,4-dihydropyrrolo[3,4-b]indol-3(2H)-one ring system via Fischer indolization between the appropriate phenylhydrazines and pyrrolidine-2,3-diones. Lithiation at the C1 position with lithium diisopropylamide following by quenching with iodomethane affords 1-methyl-1,4dihydropyrrolo[3,4-b]indol-3(2H)-ones in excellent yield.<smiles>[R]N(N)c1ccccc1</smiles>

Keywords: Indole, pyrrolo[3,4-b]indole, pyrrolo[3,4-b]indolone, Fischer indolization, pyrroline-2,3-dione 


\section{Introduction}

In continuation of our interest in the synthesis and chemistry of pyrrolo $[3,4-b]$ indoles, ${ }^{1-6}$ we desired a direct preparation of pyrrolo[3,4-b]indol-3- $(2 H)$-ones having either removable nitrogen substituents or without nitrogen substitution. Guided by the seminal work both by Southwick on the synthesis of 2,3dioxopyrrolidines $^{7-9}$ and the subsequent Fischer indolization to afford the first example of the pyrrolo[3,4$b]$ indole ring system (i.e., 1,4-dihydropyrrolo[3,4-b]indol-3(2H)-one), ${ }^{10}$ and by Welch on the first generation of a 2,4-dihydropyrrolo[3,4-b]indole, ${ }^{11}$ we now report our synthesis of new pyrrolo[3,4-b]indol-3(2H)-ones as prospective substrates for 2,4-dihydropyrrolo[3,4-b]indoles.

\section{Results and Discussion}

Our synthesis of 2-benzyl-1-methylpyrrolo[3,4-b]indol-3(2H)-one (6) is summarized in Scheme 1 . Following the literature procedures, ${ }^{8,11}$ we prepared the known 4 in good overall yield. Whereas the literature method employed sodium methoxide and dimethyl oxalate to give the methyl ester $(2, R=M e)$ in $75 \%$ yield, ${ }^{8}$ we obtained a $90 \%$ yield using sodium ethoxide and diethyl oxalate. Methylation of the $\mathrm{C}-1$ position via lithiation with lithium diisopropylamide (LDA) to generate pyrrole oxide 5 and quenching with iodomethane afforded $\mathbf{6}$ in 93\% yield. Treatment of indolone 6 with methyl lithium in diethyl ether or tetrahydrofuran at room temperature or reflux gave the labile pyrrolo[3,4-b]indole 7 in low yields (11-24\%). However, efforts to trap this species with 3,4-pyridyne afforded a complex mixture of products, which, upon attempted deamination with $\mathrm{m}$-chloroperbenzoic acid, ${ }^{12}$ gave at best a trace of $\mathrm{N}$-phenylellipticine (9) and/or the corresponding isoellipticine (not shown).
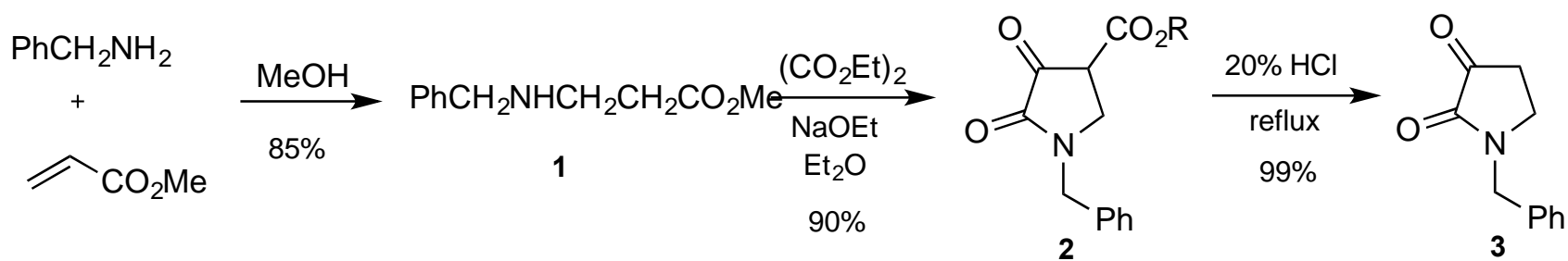

$(\mathrm{R}=\mathrm{Me}, \mathrm{Et})$

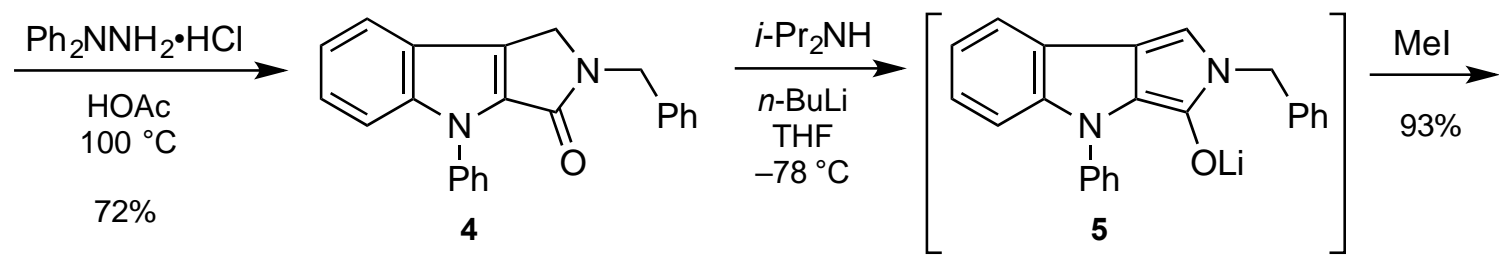




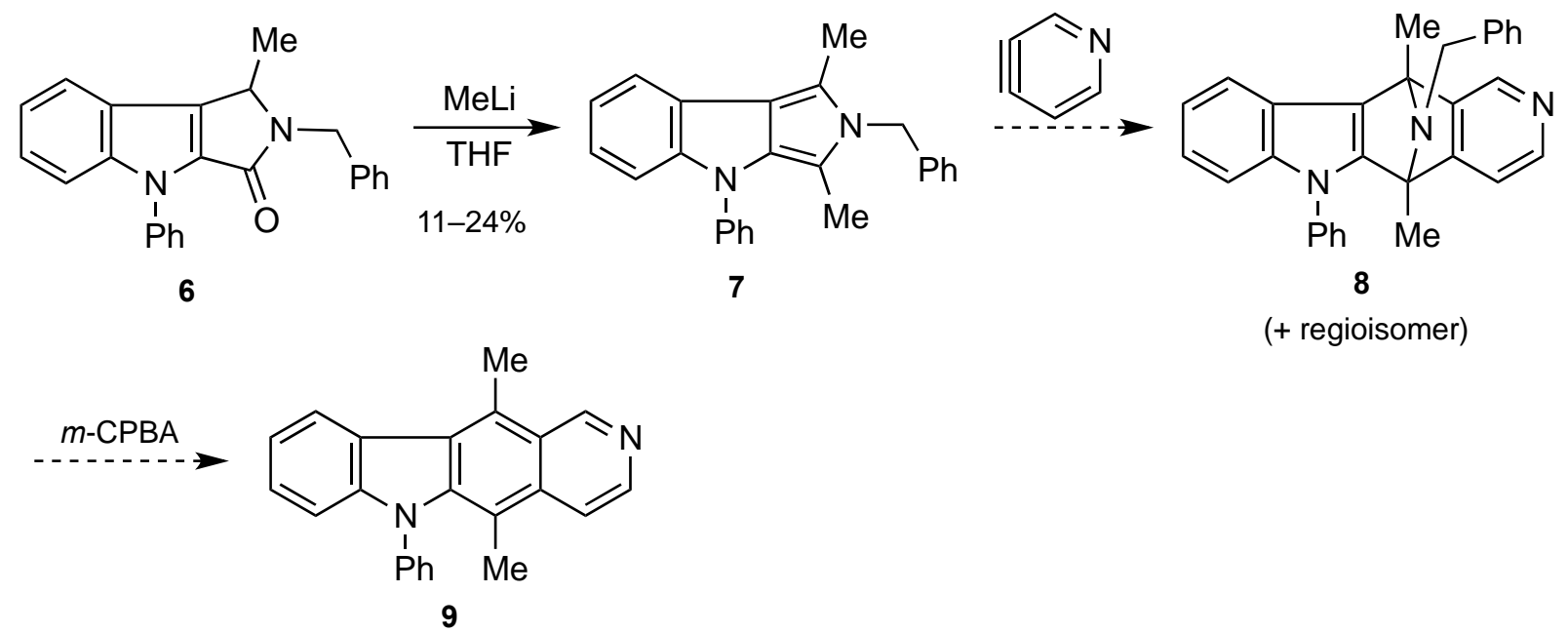

Scheme 1. Synthesis of 2-benzyl-1-methyl-4-phenyl-1,4-dihydropyrrolo[3,4-b]indol-3(2H)-one (6).

In similar fashion, we prepared the new 2,4-dibenzyl-1-methylpyrrolo[3,4-b]indol-3-one 12 from 1-benzyl-1phenylhydrazine $(\mathbf{1 0})^{13}$ and pyrrolidine-2,3-dione (3) (Scheme 2). As before, the C-1 lithiation/methylation sequence on indolone 11 proceeded in excellent yield to give 12.<smiles>CC1c2c(n(Cc3ccccc3)c3ccccc23)N(Cc2ccccc2)C(=O)C1C(=O)O</smiles>

Scheme 2. Synthesis of 2,4-dibenzyl-1-methyl-1,4-dihydropyrrolo[3,4-b]indol-3(2H)-one (12).

As shown in Scheme 3, we synthesized the first example of an unsubstituted indole nitrogen in the pyrrolo[3,4-b]indole series. Thus, 2-benzylpyrrolo[3,4-b]indole 13 was formed in $88 \%$ yield from dione 3 and phenylhydrazine. Attempts to prepare the $\mathrm{N}$-phenylsulfonyl derivative 14 failed $\left(\mathrm{KOH}, \mathrm{DMSO}, \mathrm{PhSO}_{2} \mathrm{Cl} ; n\right.$ $\mathrm{Bu}_{4} \mathrm{NHSO}_{4}, \mathrm{NaOH}, \mathrm{PhSO}_{2} \mathrm{Cl}$ ).

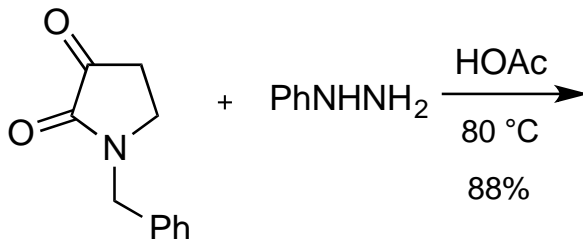

3<smiles>O=C1c2[nH]c3ccccc3c2CN1Cc1ccccc1</smiles>

13<smiles>O=C1c2c(c3ccccc3n2S(=O)(=O)O)CN1Cc1ccccc1</smiles>

14

Scheme 3. Synthesis of 2-benzyl-1,4-dihydropyrrolo[3,4-b]indol-3(2H)-one (13).

Our approach to an N(2) unsubstituted pyrrolo[3,4-b]indolone 20 is shown in Scheme 4. The known 1-(tertbutyl)pyrrolidine-2,3-dione (18) was subjected to Fischer indolization to give indolone 19 in $58 \%$ yield. 
Removal of the tert-butyl group with refluxing formic acid afforded a mixture of the desired product 20 and the $N$-formyl 21. As a result this approach was no longer pursued.

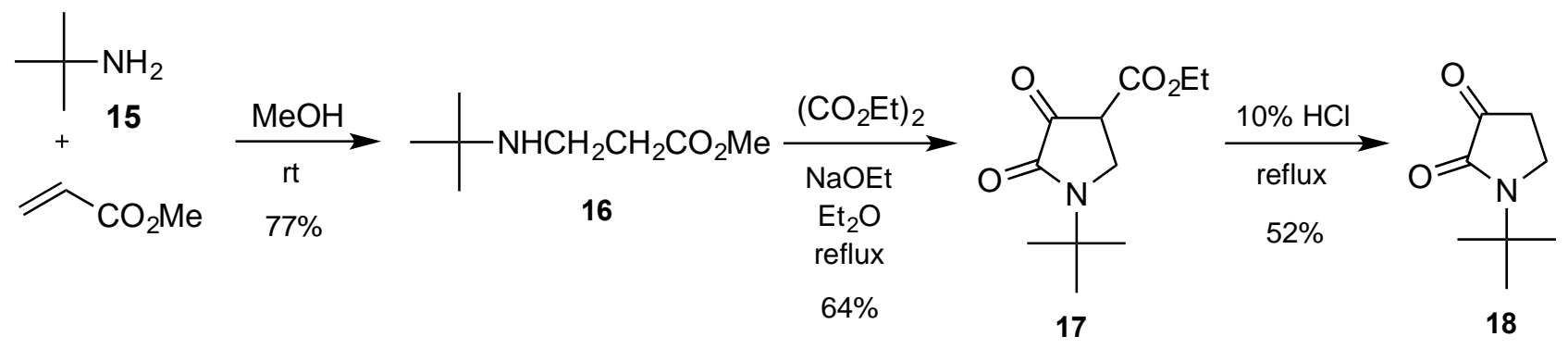

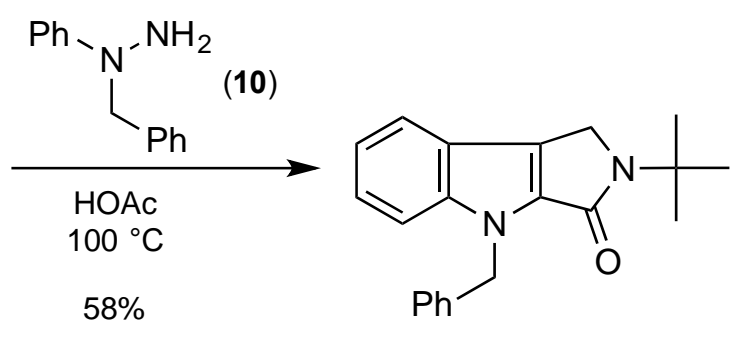

19
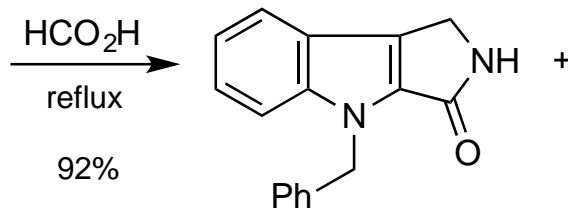

20<smiles>O=CN1Cc2c(n(Cc3ccccc3)c3ccccc23)C1=O</smiles>

21

Scheme 4. Attempted synthesis of 4-benzyl-1,4-dihydropyrrolo[3,4-b]indol-3(2H)-one (20).

\section{Conclusion}

As a designed route to pyridocarbazoles and other carbazoles via 2,4-dihydropyrrolo[3,4- $b$ ]indoles, we have synthesized the new pyrrolo[3,4-b]indolones $\mathbf{6}, \mathbf{1 1}, \mathbf{1 2}$, and $\mathbf{1 3}$, the latter of which is the first example of an $\mathrm{N}(4)$ unsubstituted pyrrolo[3,4-b]indolone. We have demonstrated a C-1 lithiation-alkylation sequence via the presumed pyrrole alkoxide 5. And, we revealed the feasibility of generating the pyrrolo[3,4- $b]$ indole 7 ring system from pyrrolo[3,4-b]indolone 6, although under these conditions trapping of 7 with 3,4-pyridyne did not succeed. The chemistry of these new pyrrolo[3,4- $b]$ indolones $\mathbf{6 , 1 1}, \mathbf{1 2}$, and $\mathbf{1 3}$ will be reported in due course.

\section{Experimental Section}

General. Melting points were determined in open capillaries with a Mel-Temp Laboratory Devices or a Büchi 510 melting point apparatus and are uncorrected. Elemental analyses were performed by Atlantic Microlabs, Atlanta, GA. Infrared spectra were recorded on a Perkin-Elmer 599 instrument or a Perkin-Elmer 1600 Fourier transform spectrometer. ${ }^{1} \mathrm{H}$ and ${ }^{13} \mathrm{C}$ NMR spectra were routinely obtained with a JEOL-FX60Q Fourier transform NMR spectrometer or a Varian XL-300 multinuclear Fourier transform instrument. Chemical shifts are reported in parts per million downfield from tetramethylsilane as the internal reference. Low resolution mass spectra were determined on a Finnigan $\mathrm{El}-\mathrm{Cl}$ gas chromatograph-mass spectrometer or a Hewlett Packard 5890 Instrument. Ultraviolet (UV) spectra were recorded on a Unicam SF-800A spectrophotometer or a Hewlett Packard 5890 Diode-Array spectrophotometer. Thin layer chromatography (TLC) was performed on 
precoated $\left(0.2 \mathrm{~mm}\right.$ ) silica gel $60 \mathrm{~F}_{254}$ plastic sheets (E. Merck). Spots were visualized under $254 \mathrm{~nm}$ UV light, an iodine chamber, and/or by spraying with a solution of $3 \%$ aqueous ceric ammonium sulfate in $10 \% \mathrm{H}_{2} \mathrm{SO}_{4}$ followed by brief heating. THF was distilled from $\mathrm{Na}$ /benzophenone and diisopropylamine was distilled from $\mathrm{NaH}$. All reactions were performed in oven-dried $\left(130^{\circ} \mathrm{C}\right)$ or flame-dried glassware under prepurified $\mathrm{Ar}$ or $\mathrm{N}_{2}$.

Methyl 3-Benzylaminopropionate (1). To a solution of benzylamine (53.58 g, $0.500 \mathrm{~mol}$ ) in absolute $\mathrm{MeOH}$ $(400 \mathrm{~mL})$ under $\mathrm{N}_{2}$ was added freshly distilled methyl acrylate $(43.05 \mathrm{~g}, 0.500 \mathrm{~mol})$. The resulting colorless mixture was allowed to stand for $24 \mathrm{~h}$ and the solvent was removed under reduced pressure to give a colorless oil which was fractionally distilled. After benzylamine $\left(53-55^{\circ} \mathrm{C} / 2\right.$ Torr) $(8.05 \mathrm{~g})$ was collected, there was obtained $69.98 \mathrm{~g}$ ( $85 \%$ based on recovered benzylamine) of 1 as a colorless liquid: bp $112-114{ }^{\circ} \mathrm{C} / 1$ Torr

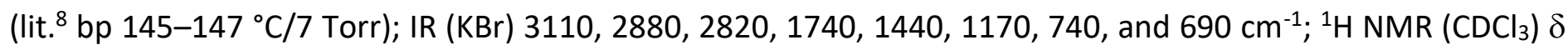
$7.28(\mathrm{~s}, 5 \mathrm{H}), 3.79(\mathrm{~s}, 2 \mathrm{H}), 3.65(\mathrm{~s}, 3 \mathrm{H}), 2.90(\mathrm{t}, 2 \mathrm{H}), 2.48(\mathrm{t}, 2 \mathrm{H}), 1.60$ (broad s, $1 \mathrm{H}$ ).

Ethyl (Methyl) 1-Benzyl-4,5-dioxopyrrolidine-3-carboxylate (2). To a solution of freshly prepared solid NaOEt $(23.31 \mathrm{~g}, 0.343 \mathrm{~mol})$ in anhydrous $\mathrm{Et}_{2} \mathrm{O}(170 \mathrm{~mL})$ under $\mathrm{N}_{2}$ was added diethyl oxalate $(50.10 \mathrm{~g}, 0.343 \mathrm{~mol})$ followed by the dropwise addition of amino ester $1(66.25 \mathrm{~g}, 0.343 \mathrm{~mol})$ in dry $\mathrm{Et}_{2} \mathrm{O}(170 \mathrm{~mL})$ over $2 \mathrm{~min}$. The resulting solution was refluxed for $0.5 \mathrm{~h}$ with magnetic stirring and then allowed to stand overnight under $\mathrm{N}_{2}$. After rotary evaporation of the solvent, the resulting pale yellow solid was dissolved in warm $\mathrm{H}_{2} \mathrm{O}(1700 \mathrm{~mL})$ and slowly acidified with $20 \% \mathrm{HCl}$ until the aqueous portions became slightly acidic. The mixture was allowed to stand for $20 \mathrm{~h}$ and the colorless precipitate was collected, washed with cold $\mathrm{H}_{2} \mathrm{O}$, and dried at $50-60{ }^{\circ} \mathrm{C} / 20$ Torr for $24 \mathrm{~h}$ to give $76.55 \mathrm{~g}(90 \%)$ of 2 as a mixture of methyl and ethyl esters: $\mathrm{mp} 139-150{ }^{\circ} \mathrm{C}(\mathrm{MeOH})$; Recrystallization of a small portion from $\mathrm{MeOH}$ gave a colorless crystalline solid mixture of the two esters (NMR) mp 136-143 ${ }^{\circ} \mathrm{C}: \quad \mathrm{IR}(\mathrm{KBr}) 3100,3020,2920,1670,1420,1230,740$, and $690\left(\mathrm{~cm}^{-1}\right) ; \mathrm{NMR}\left(\mathrm{CDCl}_{3}\right) \delta 1.30$ $(\mathrm{t}, 3 \mathrm{H}, J 6 \mathrm{~Hz}), 3.80(\mathrm{~s}, 2 \mathrm{H}), 3.90(\mathrm{~s}, 3 \mathrm{H}), 4.30(\mathrm{q}, 2 \mathrm{H}, J 6 \mathrm{~Hz}), 4.65(\mathrm{~s}, 2 \mathrm{H}), 7.38(\mathrm{~s}, 5 \mathrm{H})$, and $8.42(\mathrm{~s}, 1 \mathrm{H}) \mathrm{ppm}$. The melting point of the pure methyl ester is $\mathrm{mp} 183-184^{\circ} \mathrm{C} .^{8}$

1-Benzylpyrrolidine-2,3-dione (3). A mixture of the ester mixture 2 (6.05 g, $24.0 \mathrm{mmol}$ ) in $20 \% \mathrm{HCl}(160 \mathrm{~mL})$ was refluxed until $\mathrm{CO}_{2}$ evolution has subsided and all the material has dissolved $(2.5-3 \mathrm{~h})$. The solution was cooled and extracted with $\mathrm{CHCl}_{3}(4 \times 125 \mathrm{~mL})$. The combined extracts were washed with $\mathrm{H}_{2} \mathrm{O}(1 \times 50 \mathrm{~mL})$, dried $\left(\mathrm{Na}_{2} \mathrm{SO}_{4}\right)$, and evaporated in vacuo to afford $4.50 \mathrm{~g}$ (99\%) of 3 as an off-white solid: $\mathrm{mp} 95-97{ }^{\circ} \mathrm{C}$ (lit. ${ }^{8}$

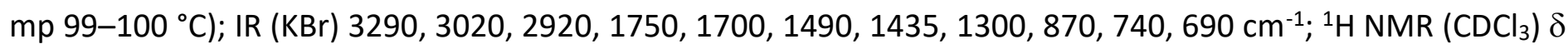
$7.31(\mathrm{~s}, 5 \mathrm{H}), 4.66(\mathrm{~s}, 2 \mathrm{H}), 3.53(\mathrm{t}, 2 \mathrm{H}), 2.60(\mathrm{t}, 2 \mathrm{H})$.

2-Benzyl-4-phenyl-1,4-dihydropyrrolo[3,4-b]indol-3-(2H)-one (4). To a suspension of 1,1-diphenylhydrazine hydrochloride $(3.20 \mathrm{~g}, 14.5 \mathrm{mmol})$ in glacial HOAc $(46 \mathrm{~mL})$ was added a solution of dione $3(2.77 \mathrm{~g}, 14.5 \mathrm{mmol})$ in glacial HOAC $(46 \mathrm{~mL})$ and the mixture was heated for $15 \mathrm{~min}$ on a steam bath. Concentrated $\mathrm{HCl}(23 \mathrm{~mL})$ was then added to the warm solution and this mixture was heated for an additional 25 min. The reaction mixture was cooled, diluted with $\mathrm{H}_{2} \mathrm{O}(75 \mathrm{~mL})$, and allowed to stand at $5{ }^{\circ} \mathrm{C}$ for $2-3 \mathrm{~h}$. The product was collected by filtration, washed several times with $\mathrm{H}_{2} \mathrm{O}$, and dried at $40-50{ }^{\circ} \mathrm{C} / 20$ Torr for $24 \mathrm{~h}$ to give $3.52 \mathrm{~g}$ (72\%) of 4 as an off-white solid, $\mathrm{mp} 138-140{ }^{\circ} \mathrm{C}$. Crystallization from EtOAc gave 4 as colorless crystals: $\mathrm{mp}$ 145-146 ${ }^{\circ} \mathrm{C}$ (lit. ${ }^{11} \mathrm{mp} 145.5-146.5{ }^{\circ} \mathrm{C}$ ); IR $\left(\mathrm{CHCl}_{3}\right)$ 3030, 1682, 1500, 1452, 1380, 1215, $690 \mathrm{~cm}^{-1} ;{ }^{1} \mathrm{H} \mathrm{NMR}$ $\left(\mathrm{CDCl}_{3}\right) \delta 7.70-7.10(\mathrm{~m}, 9 \mathrm{H}), 7.30(\mathrm{~s}, 5 \mathrm{H}), 4.76(\mathrm{~s}, 2 \mathrm{H}), 4.31(\mathrm{~s}, 2 \mathrm{H}) ; \mathrm{UV}(\mathrm{MeO}) \lambda_{\max } 246,299 \mathrm{~nm}$.

2-Benzyl-1-methyl-4-phenyl-1,4-dihydropyrrolo[3,4-b]indol-3(2H)-one (6). A magnetically stirred solution of lithium diisopropylamide (LDA) (3.7 mmol) was prepared from $i-\mathrm{Pr}_{2} \mathrm{NH}(0.38 \mathrm{~g}, 3.7 \mathrm{mmol}$ ) and $n$-BuLi (1.6 M in hexane; $2.32 \mathrm{~mL}, 3.7 \mathrm{mmol})$ in dry THF $(10 \mathrm{~mL})$ under $\mathrm{N}_{2}$ at $-78{ }^{\circ} \mathrm{C}$. After $20 \mathrm{~min}$ at $-78{ }^{\circ} \mathrm{C}$, a solution of indolone $4(1.00 \mathrm{~g}, 2.96 \mathrm{mmol})$ in dry THF $(10 \mathrm{~mL})$ was slowly added to the LDA. The resulting blue-green solution was warmed to $15{ }^{\circ} \mathrm{C}$ over $2 \mathrm{~h}$, cooled to $-78{ }^{\circ} \mathrm{C}$, and quenched with a solution of iodomethane $(0.28$ 
$\mathrm{mL}, 4.5 \mathrm{mmol})$ in dry THF ( $8 \mathrm{~mL}$ ) over $1 \mathrm{~min}$. After warming to rt overnight, the reaction mixture was partially concentrated in vacuo, and then slowly added to a solution of concentrated $\mathrm{HCl}(1 \mathrm{~mL})$ in $\mathrm{H}_{2} \mathrm{O}(50 \mathrm{~mL})$. The resulting precipitate was dissolved in EtOAc $(150 \mathrm{~mL})$ and the aqueous layer was further extracted with EtOAc $(2 \times 100 \mathrm{~mL})$. The combined organic portions were washed with $\mathrm{H}_{2} \mathrm{O}(2 \times 100 \mathrm{~mL})$, dried $\left(\mathrm{Na}_{2} \mathrm{SO}_{4}\right)$, and rotary evaporated to give $0.97 \mathrm{~g}(93 \%)$ of 6 as a light tan solid. Recrystallization from EtOAc gave the analytical sample: $\mathrm{mp} 178-179{ }^{\circ} \mathrm{C}$; IR $\left(\mathrm{CHCl}_{3}\right) 3025,1680,1500,1380,1215,690 \mathrm{~cm}^{-1} ;{ }^{1} \mathrm{H}$ NMR $\left(\mathrm{CDCl}_{3}\right) \delta 7.75-7.15(\mathrm{~m}$, 9H), $7.30(\mathrm{~s}, 5 \mathrm{H}), 5.40-4.20(\mathrm{~m}, 3 \mathrm{H}), 1.60(\mathrm{~d}, 3 \mathrm{H}, \mathrm{J} 6 \mathrm{~Hz}) ;{ }^{13} \mathrm{C} \mathrm{NMR}\left(\mathrm{CDCl}_{3}\right) \delta 161.6,141.9,137.9,136.2,133.0$, 132.7, 129.1, 128.6, 127.9, 127.3, 127.1, 125.8, 124.7, 121.7, 121.2, 119.7, 112.3, 51.3, 44.0, 18.2; UV (MeOH) $\lambda_{\max } 245,299 \mathrm{~nm}$. Anal. Calcd for $\mathrm{C}_{24} \mathrm{H}_{20 \mathrm{~N} 2} \mathrm{O}: \mathrm{C}, 81.79 ; \mathrm{H}, 5.72 ; \mathrm{N}, 7.95$. Found: C, 81.54; H, 5.75; N, 7.95.

1-Benzyl-1-phenylhydrazine (10). To a magnetically stirred solution of phenylhydrazine $(10.8 \mathrm{~g}, 0.100 \mathrm{~mol})$ in distilled $\mathrm{H}_{2} \mathrm{O}(30 \mathrm{~mL})$ were added $\mathrm{NaHCO}_{3}(20 \mathrm{~g})$ and $\mathrm{PhCH}_{2} \mathrm{Br}(11.9 \mathrm{~mL}, 0.100 \mathrm{~mol})$. The resultant mixture was refluxed for $3 \mathrm{~h}$ and then allowed to cool to $25^{\circ} \mathrm{C}$. The layers were separated and the yellow upper layer was diluted with $\mathrm{Et}_{2} \mathrm{O}(100 \mathrm{~mL})$, dried $\left(\mathrm{Na}_{2} \mathrm{SO}_{4}\right)$, and concentrated in vacuo to afford $19.6 \mathrm{~g}(99 \%)$ of 10 as a yellow oil. This material was identical by NMR with a sample prepared from the commercial hydrochloride salt, and was normally used without further purification. On standing for several weeks at $0{ }^{\circ} \mathrm{C}$ the oil darkened and was distilled, bp $125-130{ }^{\circ} \mathrm{C} / 1.5$ Torr (lit. ${ }^{13} \mathrm{bp} 157-159{ }^{\circ} \mathrm{C} / 4$ Torr); ${ }^{1} \mathrm{H}$ NMR $\left(\mathrm{CDCl}_{3}\right) \delta 3.31$ (br s, $\left.2 \mathrm{H}\right), 4.49$ (s, 2H), 6.57-7.52 (m, 5H), $7.24(\mathrm{~s}, 5 \mathrm{H})$.

2-Dibenzyl-1,4-dihydropyrrolo[3,4-b]indol-3(2H)-one (11). To a suspension of 1-benzyl-1-phenylhydrazine hydrochloride $(\mathbf{1 0}-\mathrm{HCl})(8.74 \mathrm{~g}, 0.044 \mathrm{~mol})$ in glacial $\mathrm{HOAc}(80 \mathrm{~mL})$ was added a solution of $3(7.5 \mathrm{~g}, 0.040 \mathrm{~mol})$ in glacial HOAC $(80 \mathrm{~mL})$. The resulting suspension was stirred and warmed to $80{ }^{\circ} \mathrm{C}$ over a period of approximately 20 min to effect hydrazone formation. Then concentrated $\mathrm{HCl}(45 \mathrm{~mL})$ was added to the warm solution with subsequent heating for an additional $2.5 \mathrm{~h}$. After $10 \mathrm{~min}$ more of heating at $95-100{ }^{\circ} \mathrm{C}$, the hot solution was diluted with distilled $\mathrm{H}_{2} \mathrm{O}(125 \mathrm{~mL})$ to yield $8.63 \mathrm{~g}(66 \%)$ of greenish crystalline 11. Recrystallization from EtOAc gave off-white crystals, $\mathrm{mp} 144-146{ }^{\circ} \mathrm{C}$. Pertinent spectral data for 11 are as follows: IR (KBr) 3025, 2940, 1670, 1555, 1440, 1390, 740, $690\left(\mathrm{~cm}^{-1}\right)$; NMR (CDCl $) \delta 4.30(\mathrm{~s}, 2 \mathrm{H}), 4.76(\mathrm{~s}, 2 \mathrm{H})$, 5.65 (s, 2H), 7.05-7.65 (m, 4H), 7.30 (s, 10H) ppm; UV (95\% EtOH) $\lambda_{\max } 215,232$ (sh), 298, 307 (sh) nm; MS $m / e ~ 352\left(\mathrm{M}^{+}\right), 261,247,156,128,91$ (100\%); ${ }^{13} \mathrm{C} \mathrm{NMR}\left(\mathrm{CDCl}_{3}\right) \delta$ 45.4, 46.9, 47.4, 111.6, 120.0, 120.4, 121.8, 124.1, 124.5, 127.4, 127.9, 128.5, 128.6, 134.0, 137.3, 137.5, 141.6, 162.8. Anal. Calcd for $\mathrm{C}_{24} \mathrm{H}_{20} \mathrm{~N}_{2} \mathrm{O}$ : $\mathrm{C}$, 81.79; $H, 5.72 ; N, 7.95$. Found: C, 81.90; $H, 5.79 ; N, 7.96$.

2,4-Dibenzyl-1-methyl-1,4-dihydropyrrolo[3,4-b]indol-3(2H)-one (12). To a solution of $i$ - $\operatorname{Pr}_{2} \mathrm{NH}(0.83 \mathrm{~g}$, $0.0082 \mathrm{~mol}$ ) in THF $\left(20 \mathrm{~mL}\right.$ ) (freshly distilled) at $-78{ }^{\circ} \mathrm{C}$ under $\mathrm{N}_{2}$, was added slowly, with stirring $1.70 \mathrm{M} n$ BuLi/hexane $(4.60 \mathrm{~mL}, 0.0078 \mathrm{~mol})$. After stirring for $30 \mathrm{~min}$ at $-78{ }^{\circ} \mathrm{C}$, a solution of pyrrole $11(2.5 \mathrm{~g}, 0.0071$ $\mathrm{mol})$ in THF $(20 \mathrm{~mL})$ was added, resulting in the formation of a brightly brown-colored solution. The presumed enolate was allowed to gradually warm to $15{ }^{\circ} \mathrm{C}$ over a $2.0 \mathrm{~h}$ period, cooled again to $-78{ }^{\circ} \mathrm{C}$, and then iodomethane $(2.0 \mathrm{~g}, 0.014 \mathrm{~mol})$ was added dropwise over $1 \mathrm{~min}$. After $1.0 \mathrm{~h}$, the solution had become lighter brown and it was allowed to warm to rt over $15 \mathrm{~h}$. After this period saturated $\mathrm{NaHCO}_{3}$ solution $(100 \mathrm{~mL}) \mathrm{was}$ added slowly. The resulting oil was then dissolved in $\mathrm{Et}_{2} \mathrm{O}$, the aqueous filtrate was twice extracted with EtOAc $(2 \times 100 \mathrm{~mL})$, and the combined extracts were washed with $\mathrm{H}_{2} \mathrm{O}(1 \times 100 \mathrm{~mL})$, brine $(1 \times 100 \mathrm{~mL})$, dried $\left(\mathrm{Na}_{2} \mathrm{SO}_{4}\right)$, and concentrated in vacuo to give $2.43 \mathrm{~g}(94 \%)$ of 12 as a viscous oil that crystallized under $\mathrm{N}_{2}$. Recrystallization from EtOAc (3X) gave 12 as off-white crystals, mp 117.5-119 ${ }^{\circ} \mathrm{C}$; IR (KBr) 3040, 2930, 1670, 1550, 1480, 1440, 1375, 1215, 735, $690 \mathrm{~cm}^{-1}$; NMR $\left(\mathrm{CDCl}_{3}\right) \delta 1.55(\mathrm{~d}, 3 \mathrm{H}, \mathrm{J}=6 \mathrm{~Hz}), 4.20-5.40(\mathrm{~m}, 3 \mathrm{H}), 5.65(\mathrm{~s}$, 2H), 7.05-7.70 (m, 14H) ppm; ${ }^{13} \mathrm{C} N M R\left(\mathrm{CDCl}_{3}\right) \delta 18.3,43.9,47.6,51.7,111.7,119.7,120.4,121.5,124.0$, $127.3,127.4,127.8,128.6,130.4,133.3,137.3,137.8,141.7,162.4$; UV (95\% EtOH) $\lambda_{\max } 208,222$ (sh), 300, 
310 (sh) nm; MS, m/e $366\left(\mathrm{M}^{+}\right), 351,275,260,247,170,140,91$ (100\%). Anal. Calcd for $\mathrm{C}_{25} \mathrm{H}_{22} \mathrm{~N}_{2} \mathrm{O}: \mathrm{C}, 81.94$; $\mathrm{H}, 6.05 ; \mathrm{N}, 7.64$. Found: C, 81.83; H, 5.85; N, 7.96.

2-Benzyl-1,4-dihydropyrrolo[3,4-b]indol-3(2H)-one (13). To a suspension of phenylhydrazine (1.73 g, 0.0155 mol) in glacial HOAc (55 mL) was added a solution of $3(2.80 \mathrm{~g}, 0.0148 \mathrm{~mol})$ in glacial HOAc (55 mL), and the resulting solution was warmed to $80{ }^{\circ} \mathrm{C}$ over a period of about $10 \mathrm{~min}$ to effect hydrazone formation. Concentrated $\mathrm{HCl}(30 \mathrm{~mL})$ was added to the warm solution, with subsequent heating for an additional $2.5 \mathrm{~h}$. After 10 min more of heating at $90-100{ }^{\circ} \mathrm{C}$, the hot solution was diluted with distilled $\mathrm{H}_{2} \mathrm{O}(125 \mathrm{~mL})$ to yield $3.44 \mathrm{~g}(88 \%)$ of an off-white solid (13). Crystallization from EtOAc gave an off-white fluffy powder, $\mathrm{mp} 282-$ $286^{\circ} \mathrm{C}$, and recrystallization from EtOAc gave the analytical sample of 13 as very light, fluffy needles: $\mathrm{mp} 290-$ $293^{\circ} \mathrm{C}$ dec; IR (KBr) 3195, 1650, 1450, 1340, 750, $710 \mathrm{~cm}^{-1}$; NMR (CDCl $) \delta 3.80$ (broad, 1H), 4.45 (s, $\left.2 \mathrm{H}\right), 4.80$ $(\mathrm{s}, 2 \mathrm{H}), 7.0-7.4(\mathrm{~s}, 9 \mathrm{H}) \mathrm{ppm} ;{ }^{13} \mathrm{C}$ NMR $\left(d_{6}\right.$-DMSO) $\delta 45.6,46.1,113.3,119.9,121.5,123.8,125.0,127.2,128.6$, 134.2, 138.1, 141.3, 162.1; UV (95\% EtOH) $\lambda_{\max }{ }^{\mathrm{EtOH}} 220,235$ (sh), 298, 307 (sh) nm; MS, m/e $262\left(\mathrm{M}^{+}\right), 171$, 157, 129, 106, 91 (100\%). Anal. Calcd for $\mathrm{C}_{17} \mathrm{H}_{14} \mathrm{~N}_{2} \mathrm{O}$ : C, 77.84; $\mathrm{H}, 5.38 ; \mathrm{N}, 10.68$. Found: C, 77.76; $\mathrm{H}, 5.41 ; \mathrm{N}$, 10.63.

Methyl 3-(tert-Butylamino)propionate (16). To a solution of tert-butyl amine (15) $(34.8 \mathrm{~g}, 0.48 \mathrm{~mol}, 50 \mathrm{~mL})$ in $\mathrm{MeOH}\left(380 \mathrm{~mL}\right.$ ) under $\mathrm{N}_{2}$ was added freshly distilled methyl acrylate $(41.3 \mathrm{~g}, 0.48 \mathrm{~mol}, 43.2 \mathrm{~mL})$. The resulting colorless solution was allowed to stand for $96 \mathrm{~h}$ under $\mathrm{N}_{2}$. The solvent was removed under reduced pressure. The crude product was collected by vacuum distillation at $82{ }^{\circ} \mathrm{C} / 10$ Torr (lit. ${ }^{15} \mathrm{bp} 63{ }^{\circ} \mathrm{C} / 10$ Torr) to yield $58.5 \mathrm{~g}$ (77\%) of (16) as a colorless liquid, which was used directly in the next step; ${ }^{1} \mathrm{H}$ NMR $\delta 3.65(\mathrm{~s}, 3 \mathrm{H}), 3.32(\mathrm{~s}, 1 \mathrm{H})$, $2.80(\mathrm{~m}, 2 \mathrm{H}), 2.47(\mathrm{~m}, 2 \mathrm{H}), 1.07(\mathrm{~s}, 9 \mathrm{H}) ; \mathrm{IR} 2950,1749 \mathrm{~cm}^{-1}$.

Ethyl 1-(tert-Butyl)-4,5-dioxopyrrolidine-3-carboxylate (17). To a solution of freshly prepared solid NaOEt (19.6 g, $288 \mathrm{mmol})$ in anhydrous ether $(125 \mathrm{~mL})$ under $\mathrm{N}_{2}$ was added diethyl oxalate $(42.2 \mathrm{~g}, 288 \mathrm{mmol})$ followed by dropwise addition of amino ester $16(45.8 \mathrm{~g}, 288 \mathrm{mmol})$ in dry ether $(125 \mathrm{~mL})$ over a period of 5 min. The resulting solution was heated at reflux for $30 \mathrm{~min}$ and then let stand overnight. The solvent was removed and the resulting pale yellow solid was dissolved in $\mathrm{H}_{2} \mathrm{O}(1500 \mathrm{~mL})$ and then acidified slightly with $20 \%$ aqueous $\mathrm{HCl}$. The mixture was placed in a separatory funnel and the organic layer separated. The aqueous layer was allowed to stand for $24 \mathrm{~h}$, which yielded $31.9 \mathrm{~g}$ of $\mathbf{1 7}$ as white crystals. The organic layer was evaporated under reduced pressure to yield an additional $7.3 \mathrm{~g}$ of 17 , for a combined $39.2 \mathrm{~g}$ (64\%) of 17. Recrystallization from petroleum ether $\left(60-120{ }^{\circ} \mathrm{C}\right.$ ) gave $\mathrm{mp} 120-122^{\circ} \mathrm{C}$ (lit. ${ }^{9} \mathrm{mp} 126.5-127.5^{\circ} \mathrm{C}$ ). (Enolic form) ${ }^{1} \mathrm{H}$ NMR $\delta 4.33(\mathrm{q}, 2 \mathrm{H}, \mathrm{J} 7.0 \mathrm{~Hz}$ ), $4.04(\mathrm{~s}, 2 \mathrm{H}), 3.85(\mathrm{~s}, 1 \mathrm{H}), 1.49(\mathrm{~s}, 9 \mathrm{H}), 1.34(\mathrm{t}, 3 \mathrm{H}, \mathrm{J} 7.0 \mathrm{~Hz})$.

1-(tert-Butyl)pyrrolidine-2,3-dione (18). A solution of $10.0 \mathrm{~g}(0.044 \mathrm{~mol})$ of amino ester (17) in $10 \%$ aqueous $\mathrm{HCl}(250 \mathrm{~mL})$ was heated at reflux until $\mathrm{CO}_{2}$ evolution had ceased and all of the material had dissolved (2.5 $\mathrm{h}$ ). The reaction mixture was cooled to $\mathrm{rt}$ and extracted with $\mathrm{CH}_{2} \mathrm{Cl}_{2}(3 \times 50 \mathrm{~mL})$. The combined organic extracts were washed with $\mathrm{H}_{2} \mathrm{O}$, and then dried $\left(\mathrm{Na}_{2} \mathrm{SO}_{4}\right)$. The solvent was removed under reduced pressure to yield $3.8 \mathrm{~g}(52 \%)$ of $(18)$ as a crystalline orange solid; mp $97-99{ }^{\circ} \mathrm{C}$ (lit. $\left.{ }^{9} \mathrm{mp} 103.5-104{ }^{\circ} \mathrm{C}\right) ;{ }^{1} \mathrm{H} \mathrm{NMR} \delta 3.74(\mathrm{~m}, 2 \mathrm{H})$, $2.67(\mathrm{~m}, 2 \mathrm{H}), 1.50(\mathrm{~s}, 9 \mathrm{H})$.

4-Benzyl-2-(tert-butyl)-1,4-dihydropyrrolo[3,4-b]indol-3(2H)-one (19). To a stirred suspension of 1-benzyl-1phenylhydrazine (10) $(1.98 \mathrm{~g}, 10.0 \mathrm{mmol})$ in glacial HOAc (30 mL) was added a solution of dione 18 (1.55 g, $10.0 \mathrm{mmol})$ in glacial $\mathrm{HOAC}(30 \mathrm{~mL})$ and the mixture was heated for $15 \mathrm{~min}$ on a steam bath. Concentrated $\mathrm{HCl}$ $(15 \mathrm{~mL})$ was added to the warm solution and the resulting solution heated for an additional 35 min on the steam bath. The reaction mixture was cooled, diluted with $\mathrm{H}_{2} \mathrm{O}(50 \mathrm{~mL})$, and allowed to stand at $5{ }^{\circ} \mathrm{C}$ overnight. Filtration of the resulting product gave $0.37 \mathrm{~g}$ of 19 . The filtrate was extracted with $\mathrm{CH}_{2} \mathrm{Cl}_{2}$ and the organic layer was washed with aqueous $10 \% \mathrm{NaOH}, \mathrm{H}_{2} \mathrm{O}$, and dried $\left(\mathrm{Na}_{2} \mathrm{SO}_{4}\right)$. Evaporation gave an additional $1.6 \mathrm{~g}$ of 19 as a tan solid. The solids were combined and recrystallized from EtOH to give $1.85 \mathrm{~g}(58 \%)$ of 19 as 
an off-white solid, $\mathrm{mp} 196-198{ }^{\circ} \mathrm{C}$, which was used directly in the next step; ${ }^{1} \mathrm{H}$ NMR $\delta 7.16-8.17(\mathrm{~m}, 9 \mathrm{H}), 5.59$ $(\mathrm{s}, 2 \mathrm{H}), 4.46$ (s, 2H), 1.59 (s, 9H); ${ }^{13} \mathrm{C}$ NMR $\delta 163.7,141.5,137.5,128.6,128.5,127.4,127.3,123.8,123.3,121.5$, $120.3,119.9,111.7,55.0,47.1,44.0,28.2$.

4-Benzyl-1,4-dihydropyrrolo[3,4-b]indol-3(2H)-one $\quad(20)$ and 4-Benzyl-2-formyl-1,4-dihydropyrrolo[3,4b]indol-3(2H)-one (21). A solution of pyrroloindolone $19(0.135 \mathrm{~g}, 0.42 \mathrm{mmol})$ in $\mathrm{HCOOH}(5 \mathrm{~mL})$ was heated at reflux for $2 \mathrm{~h}$. Water $(10 \mathrm{~mL})$ was added while the solution was hot and the reaction was allowed to cool to rt. The resulting product was filtered to give $0.101 \mathrm{~g}$ (92\%) of a mixture of $\mathbf{2 0}$ and $\mathbf{2 1}$ as an off-white solid, mp 195 ${ }^{\circ} \mathrm{C} \mathrm{dec} ;{ }^{1} \mathrm{H}$ NMR $\delta$ 7.70-7.22 (m, 9H), 5.59 (s, 2H), 4.83 (s, 2H), 1.65 (br s, 1H); ${ }^{13} \mathrm{C}$ NMR $\delta$ 159.6, 143.5, 136.6, 130.8, 129.6, 128.7, 127.9, 127.5, 124.4, 121.4, 121.3, 121.2, 111.8, 47.8, 41.8; IR 3290, $1672 \mathrm{~cm}^{-1}$; MS m/e (relative intensity): 262 (24), 234 (13.5), 185 (9), 91 (100). This mixture was not further characterized.

\section{Acknowledgements}

We acknowledge and thank Dartmouth College and the Donors of the Petroleum Research Fund, administered by the American Chemical Society, for support of this work.

\section{References}

1. Pelkey, E. T.; Gribble, G. W. Chem. Commun. 1997, 1873. https://doi.org/10.1039/A704217E

2. Gribble, G. W.; Pelkey, E. T.; Simon, W. M.; Trujillo, H. A. Tetrahedron 2000, 56, 10133. https://doi.org/10.1016/S0040-4020(00)00858-9

3. Kishbaugh, T. L. S.; Gribble, G. W. Synth. Commun. 2002, 32, 2003. https://doi.org/10.1081/SCC-120004850

4. Pelkey, E. T.; Gribble, G. W. Can. J. Chem. 2006, 84, 1338. https://doi.org/10.1139/v06-075

5. Roy, S.; Kishbaugh, T. L. S.; Jasinski, J. P.; Gribble, G. W. Tetrahedron Lett. 2007, 48, 1313. https://doi.org/10.1016/j.tetlet.2006.12.125

6. Rinderspacher, A.; Gribble, G. W. Molecules 2020, 25, 261. https://doi.org/10.3390/molecules25020261

7. Southwick, P. L.; Seivard, L. L. J. Am. Chem. Soc. 1949, 71, 2532. https://doi.org/10.1021/ja01175a083

8. Southwick, P. L.; Crouch, R. T. J. Am. Chem. Soc. 1953, 75, 3413. https://doi.org/10.1021/ja01110a034

9. Southwick, P. L.; Previc, E. P.; Casanova, Jr., J.; Carlson, E. H. J. Org. Chem. 1956, $21,1087$. https://doi.org/10.1021/jo01116a009

10. Southwick, P. L.; Owellen, R. J. J. Org. Chem. 1960, 25, 1133.

https://doi.org/10.1021/jo01077a017

11. Welch, W. M. J. Org. Chem. 1976, 41, 2031.

https://doi.org/10.1021/jo00873a033

12. Gribble, G. W.; Allen, R. W.; Anderson, P. S.; Christy, M. E.; Colton, C. D. Tetrahedron Lett. 1976, 3673. https://doi.org/10.1016/S0040-4039(00)93078-8 
13. Audrieth, L. F.; Weisiger, J. R.; Carter, H. E. J. Org. Chem. 1941, 6, 417. https://doi.org/10.1021/jo01203a006

14. Perni, R. B.; Gribble, G. W. Org. Prep. Proc. Int. 1982, 14, 343. https://doi.org/10.1080/00304948209354927

15. Aelony, D. J. Appl. Polymer Sci. 1969, 13, 227. https://doi.org/10.1002/app.1969.070130121

This paper is an open access article distributed under the terms of the Creative Commons Attribution (CC BY) license (http://creativecommons.org/licenses/by/4.0/) 